\title{
Improving Rooting Characteristics in Air-layers of Ficus elastica var. decora Using Indole-3-butyric Acid (IBA) in the Presence of Bacillus subtilis and Arbuscular Mycorrhizal Fungi
}

\author{
Mousa, G.T.; S.S.A. Abdel-Rahman; O.H.M. Ibrahim and Hala B. Soliman \\ Department of Ornamental Plants and Landscape Gardening, Faculty of Agriculture, \\ Assiut University \\ Received on: $12 / 3 / 2019$
}

Accepted for publication on: 17/3/2019

\begin{abstract}
The current experiment was conducted to study the response of Ficus elastica var. decora air-layers to seven treatments of IBA (control, 50 and $100 \mathrm{ppm}$ in rooting substrate, 1500 and 3000 ppm by painting girdled zone, and 1500 and $3000 \mathrm{ppm}$ in talc paste) in the presence of root promoting microorganisms including Bacillus subtilis and arbuscular mycorrhizal fungi (AMF). The obtained results indicated that $3000 \mathrm{ppm}$ IBA applied by painting girdled zone gave a significant increase in rooting percentage and the best root and growth characteristics (number of days for root appearance, number, length, fresh and dry weights of roots per rooted air-layer, survival percentage, plant height and number of leaves and shoots) as well as total content of carbohydrates and phenolics, and showed the shortest period required for root appearance in comparison with the other treatments. Air-layers treated with B. subtilis were superior to those treated with AMF. The best results concerning rooting percentage, root characteristics, total contents of carbohydrates and phenolics, survival percentage, increment in growth of air-layers after six months from detachment were observed in airlayers treated with 3000 ppm IBA by painting girdled zone in combination with B. subtilis followed by the same IBA treatment combined with AMF.
\end{abstract}

\section{Keywords: Ficus elastica var. decora, IBA, beneficial microorganisms, air layering}

\section{Introduction}

$F$. elastica var. decora, belonging family Moraceae, is one of the best known figs cultivated throughout the world. This species was formerly important as a source of an inferior natural rubber. Several cultivars are grown including cv. 'Decora' (F. decora Hort.) with leaves dark glossy green, ivory midribs, and red beneath (Baily, 1963).

Rubber fig is propagated through sexual and asexual methods. In sexual method, seed is employed only to produce new varieties by hybridization and for rootstock purpose. In asexual method, it can be successfully propagated by cuttings, air lay- ering, grafting and budding. Although multiplication through cutting is the common method, the problem lies in the very low or undesirable percentage of success. On the other hand, air layering is a well-known method for vegetative propagation of economically important woody plants. Comparing to other vegetative propagation methods, air layering is reliable and easy means of propagation, especially in species, which are difficultto-root on cuttings. The retention of desirable characteristics, the creation of uniform rootstock and the ability to mass production of identical plants quickly and efficiently are all advantages of asexual propagation which 
all can be fulfilled through air layering (Paul and Aditi, 2009). The success of air layering as a practice in propagation is probably due, in part, to the effect of endogenous auxins accumulating at the base of the girdled shoots (Cameron and Thompson, 1969). Propagation by air layering has been reported for several ornamental Ficus species such as F. benjamina, $F$. triangularis, F. microcarpa and $F$. carica as stated by Gamlath et al. (2010) and Reddy et al. (2014).

Transplanting rooted layers and stem cuttings with good root system may give better adaptation in the field and thus ultimately resulting in good performance, survival and growth. The importance of long root system is that it should allow the uptake of nutrients outside the initial exhaustion zone (Clark et al., 2000). To promote root formation and improved roots and vegetative growth characteristics, IBA is one of the most effective and widely used for this purpose, exhibiting low toxicity, low mobility, and high chemical stability (Hartmann et al., 2011).

There are many application methods for auxins to ensure high successful rate propagation through air laying, including direct application of auxin at the girdled zone, talc paste or application of auxins into the rooting substrate with dilute concentrations.

Singh et al., (2007) recorded the best rooting and growth results due to the treatment of air-layers with the highest concentration of IBA $(6000$ ppm) directly at the girdled zone. In an experiment conducted by Porlingis et al. (1999) on air layering of olive, they evaluated several factors including IBA incorporated in the paste. They found that the lanolin-Tween 20 paste $(3: 1 \mathrm{w} / \mathrm{w})$ compared with lanolin alone, in the presence of IBA, accelerated rooting and finally increased rooting percentage and root number and weight. Another method is by application of auxin in dilute concentrations into the rooting substrate (Wells, 1986 on Mahonia aquifolium and Gilani et al., 2018 on guava).

In addition to using the synthetic auxins, natural biostimulants such as plant growth promoting rhizobacteria (PGPR) and Arbuscular Mycorrhizal Fungi (AMF) play an essential role in improving rooting performance particularly for the development of lateral roots which are the preferred infection sites for the fungi (Ludwig-Muller and Guther, 2007, Abdel-Rahman and El-Dsouky, 2010 and Rajan and Radhakrishna, 2013). The mechanisms involved in plant growth promotion by these beneficial microorganisms involve producing substances such as phytohormones and polyphenolic compounds (Barea and Azon-Aguilar, 1982, Mitchell et al., 1986, Goto, 1990 and Scagel et al., 2003).

Therefore, the current study aimed to define the effect of auxin application methods with or without beneficial microorganisms (B. subtilis or AMF) on rooting and survival percentage, as well as root and growth characteristics of Ficus elastica var. decora propagated by air layering. 


\section{Materials and Methods}

This study was carried out at the Floriculture Farm, Faculty of Agriculture, Assiut University, Egypt, during the 2016 and 2017 seasons to clarify the effects of different application methods of indole-3-butyric acid (IBA) and/or B. subtilis and AMF on rooting and survival percentages as well as root and growth characters of $F$. elastica var. decora propagating by air layering.

Active strains of $B$. subtilis and AMF (Glomus intraradices) were obtained from the Unit of Biofertilizers, Fac. Agric., Ain Shams Univ., Shobra El-Kheima, Egypt. Bacterial suspension prepared of B. subtilis $\left(10^{8}\right.$ $\mathrm{CFU} / \mathrm{ml})$ and $\mathrm{AMF}$ inoculum (2500 spores/1 ) were supplied to rooting substrate at a rate of $10 \mathrm{ml} /$ layer for each of them after girdling process of $F$. elastica var. decora shoots.

Air layering of $F$. elastica var. decora was carried out by removing $2.0 \mathrm{~cm}$ ring of bark in the intermodal region from mature shoots (ca. 120 $\mathrm{cm}$ long). The layering process was done at the beginning of March for both seasons. Air-layers were treated with IBA alone or in combination with B. subtilis or AMF. The rooting substrate used was a mixture of perlite and peat moss (1:1 in volume). The layers were covered with transparent plastic bags and the both ends were secured firmly and then covered with aluminum foil. The un-treated air-layers (control) were treated with distilled water alone.

The experiment was arranged in split-plot design, with three replicates. Application methods of auxin (control, 50 and 100 ppm IBA in rooting substrate, 1500 and 3000 ppm
IBA by painting girdled zone, 1500 and 3000 ppm IBA in talc paste) were represented in the main plots, whereas, the beneficial microorganisms (control, B. subtilis and AMF) were represented in the sub-plots. Each experimental unit included 5 air-layers. The air-layers were kept under constant observation to prevent from any mechanical damage and loss of moisture.

After 10 weeks from layering, the air-layers were separated from mother plants. The roots of the separated air-layers were washed in water to remove adhering rooting substrate. Data were recorded on number of days for appearance of roots, rooting percentage, number of roots, root length, fresh and dry weights of roots per rooted air-layer. Plant height and number of leaves and shoots as well as survival percentage were recorded after 6 months from transplanting the layers in polyethylene bags filled with clay soil and were kept under plastic house conditions.

For determining total carbohydrates and phenols, as well as endogenous phytohormones and anatomy structure, the basal $2.5-3.0 \mathrm{~cm}$ portion of rooted shoots was used. Some samples were oven-dried at $70^{\circ} \mathrm{C}$ for 48 hours and ground to a fine powder and stored until used for determination of total carbohydrates and phenols. Total carbohydrates content was colorimetrically determined using anthrone sulphuric acid method described by Fales (1951). The total phenolic content was estimated colorimetrically by Folinciocalteau reagent (FCR) method (Maliauskas et al., 2004). 
Endogenous phytohormones in tissues of layered shoots bases were analyzed using GC-MS (7890A5975B) Gas Chromatograph Mass equipped with a flame ionization detector for separation of phytohormones constituents. The chromatograph apparatus was fitted with capillary colum DB- $5 \mathrm{~ms}$. The oven temperature was set at $40^{\circ} \mathrm{c}$ for $2 \mathrm{~min}$., then temperature program ramp increase with a rate of $10^{\circ} \mathrm{c} / \mathrm{min}$ to $150^{\circ}$ c for 3 min., then it was increased at the rate of $10^{\circ} \mathrm{c} / \mathrm{min}$ to $220^{\circ} \mathrm{c}$ for 6 min and then at $15^{\circ} \mathrm{c} / \mathrm{min}$ to $280^{\circ} \mathrm{c}$ for $15 \mathrm{~min}$ and finally the a post run was at $260^{\circ} \mathrm{c}$ for $2 \mathrm{~min}$. Flow rates of gases was $0.5 \mathrm{~mL} / \mathrm{min}$ for $10.9 \mathrm{~min}$ then $1 \mathrm{~mL} / \mathrm{min}$ for $30 \mathrm{~min}$. Detector and injector temperatures were $300^{\circ}$ $\mathrm{C}$ and $260^{\circ} \mathrm{C}$, respectively. Hence, the total run time was $48 \mathrm{~min}$. The obtained chromatogram and report of GC Mass analysis for each sample were analyzed to calculate the percentage of main components of phytohormones (indole acetic acid and its derivatives, zeatin and gibberellic acid).

Data obtained during the two seasons of the study were statistically analyzed using Statistix 8.1 analytical software and the means were compared using a least significant difference (L.S.D.) test based on Gomez and Gomez (1984).

\section{Results and Discussion \\ Rooting percentage}

Data presented in Table 1 show significant effects of different application methods of IBA on rooting percentage of $F$. elastica var. decora air-layers during both seasons. The best application method of IBA was the direct application by painting girdled zone which showed superiority over the other methods. The effect of IBA concentration was also obvious on rooting percentage. Treating airlayers with $3000 \mathrm{ppm}$ IBA by painting girdled zone resulted in the highest rooting percentage (93.3 and $86.7 \%$ ) in both seasons, respectively. These results are in agreement with the findings of Ray et al. (2001), Chawla (2011), Reddy et al. (2014) and Baghel et al. (2016). The stimulatory effect of IBA in increasing rooting percentage may be due to the important roles of auxin including accumulation of metabolites at the site of application of auxin, stimulation of cell division, cell elongation, root formation, enhanced hydrolysis of carbohydrates, synthesis of RNA, enzymes, new protein and cell-wall components and stem elongation (Lwin et al., 2012 and Kasem and Abd El-Baset, 2014). 
Table 1. Percentage of rooted layers in Ficus elastica var. decora as affected by IBA treatments and beneficial microorganisms during the 2016 and 2017 seasons.

\begin{tabular}{|c|c|c|c|c|c|c|c|c|c|}
\hline \multirow{3}{*}{\multicolumn{2}{|c|}{$\begin{array}{c}\text { IBA } \\
\text { application methods } \\
\text { "ppm" }\end{array}$}} & \multicolumn{8}{|c|}{ Beneficial microorganisms } \\
\hline & & \multicolumn{4}{|c|}{ First season (2016) } & \multicolumn{4}{|c|}{ Second season (2017) } \\
\hline & & Cont. & Bacillus & AMF & Mean & Cont. & Bacillus & AMF & Mean \\
\hline \multicolumn{2}{|c|}{ Control (non-treated) } & 53.33 & 60.00 & 60.00 & 57.78 & 46.67 & 60.00 & 60.00 & 55.56 \\
\hline \multirow{2}{*}{ In the substrate } & 50 & 66.67 & 80.00 & 80.00 & 75.56 & 66.67 & 73.33 & 80.00 & 73.33 \\
\hline & 100 & 73.33 & 86.67 & 80.00 & 80.00 & 66.67 & 80.00 & 73.33 & 73.33 \\
\hline \multirow{2}{*}{ By painting } & 1500 & 73.33 & 100.00 & 93.33 & 88.89 & 66.67 & 80.00 & 80.00 & 75.56 \\
\hline & 3000 & 80.00 & 100.00 & 100.00 & 93.33 & 73.33 & 100.00 & 86.67 & 86.67 \\
\hline \multirow{2}{*}{ Talc paste } & 1500 & 73.33 & 86.67 & 80.00 & 80.00 & 66.67 & 80.00 & 73.33 & 73.33 \\
\hline & 3000 & 80.00 & 100.00 & 86.67 & 88.89 & 73.33 & 86.67 & 80.00 & 80.00 \\
\hline \multicolumn{2}{|l|}{ Mean } & 71.43 & 87.62 & 82.86 & & 65.71 & 80.00 & 76.19 & \\
\hline \multicolumn{2}{|l|}{ LSD at 0.05} & & & & & & & & \\
\hline \multicolumn{2}{|l|}{ IBA Treatments } & \multicolumn{4}{|c|}{1.94} & \multicolumn{4}{|c|}{3.58} \\
\hline \multirow{2}{*}{\multicolumn{2}{|c|}{ Microorganisms }} & \multirow{2}{*}{\multicolumn{4}{|c|}{$\begin{array}{l}1.05 \\
2.79\end{array}$}} & \multirow{2}{*}{\multicolumn{4}{|c|}{2.2}} \\
\hline & & & & & & & & & 5.82 \\
\hline
\end{tabular}

Cont. $=$ control, $\mathrm{AMF}=$ Arbuscular Mycorrhizal Fungi, Bacillus $=$ Bacillus subtilis

The results also highlight the importance of the treatment with beneficial microorganisms to improve rooting percentage. Air-layers treated with $B$. subtilis had significantly higher rooting percentage $(83.8 \%$ as average mean of both seasons) than the layers treated with AMF and the control. This is consistent with the previously reported by Goto (1990), Rinallo et al. (1999) and Rajan and Radhakrishna (2013). Also, McAfee et al. (1993) showed that rooting of Pinus and Larix cuttings was higher when they were inoculated with Agrobacterium rhizogenes. Esitken et al. (2003) and Ercisli et al. (2004) tested plant growth promoting rhizobacteria (PGPR) for rooting in rose hip and sour cherry cuttings and found that PGPR were effective to obtain high rooting percentages. Root induction by beneficial microorganisms is the accepted result of phytohormones, such as IAA production, inhibition of ethylene synthesis and mineralization of nutrients (Goto, 1990, Steenhoudt and Vanderleyden, 2000 and Erturk et al., 2010).
The interaction between IBA application methods and beneficial microorganisms exerted significant differences in both seasons. The combined treatment of IBA at 3000 ppm by painting girdled zone and $B$. subtilis resulted in the highest rooting percentage $(100 \%)$ in both seasons, followed by the same IBA treatment + AMF (Table 1). These results are in accordance with Rinallo et al. (1999), Scagel, et al. (2003), Yasser (2015) and Zenginbal and Demir (2018). They revealed that IBA-bacteria or IBA-mycorrhizal fungi combined treatments showed greater capacity than IBA or beneficial microorganisms alone treatments in enhancing rooting percentage.

\section{Root and vegetative growth charac-} teristics

It is evident from the data in Tables 2-6 and Figs. $1 \& 2$ that the treatment of $F$. elastica var. decora air-layers with IBA alone or in combination with beneficial microorganisms significantly increased all root and vegetative growth characteristics compared to the control. 
Concerning IBA effect, treating air-layers with IBA at $3000 \mathrm{ppm}$ by painting girdled zone induced significantly faster root appearance and gave higher number and length of roots as well as heavier fresh and dry weights of roots. Also, the same treatment gave the same trend in increasing vegetative growth characteristics (plant height, number of shoots and leaves per rooted layer) after 6 months from transplanting compared to the control and the other treatments in both seasons. These results are in agreement with those obtained by Singh and Singh (1996), Dharshan (2008), Rymbai and Reddy (2010) and Reddy et al. (2014). Gilani et al. (2018) reported that application of IBA at $150 \mathrm{ppm}$ into the rooting substrate increased root and shoot characteristics of guava air-layers. Also, Reddy et al. (2014) indicated that Ficus carica air-layers treated with IBA at $3000 \mathrm{ppm}$ reduced number of days required for root appearance, highest number of roots, maximum root length, maximum fresh and dry weights of roots, maximum survival percentage of air-layers and number of new leaves planting. Better root and shoot promoting activity of IBA could be attributed to its property of slow movement and its relatively slow destruction by auxin degrading enzyme system (Chovatia and Singh, 2000, Dharshan, 2008 and Kumar, 2011). This also may be due to the fact that early root initiation might have provided enough time for higher rate of cell division and cell elongation which ultimately might have promoted higher length of roots. $\mathrm{Cu}-$ mulative root length had a positive relation with the number of roots per rooted layer. Therefore, IBA affect the root length either through increasing the number of roots per rooted layer or by increasing cell division and enlargement at each root (Dessalegn and Reddy, 2003). IBA most probably enhanced the translocation of carbohydrate and other endogenous plant substances and nutrients to the rooting zone for root initiation and development of the layered shoots (Yeboah et al., 2014).

As for the effect of beneficial microorganisms, inoculation of airlayers with B. subtilis or AMF resulted in early root appearance and better root and shoot characteristics comparing to the control, where $B$. subtilis was superior to AMF. These results are in accordance with those revealed by Rinallo et al. (1999), Abdel-Rahman and El-Naggar (2014) and Yasser (2015). The increase in root production observed with the mycorrhizal treatments may be related to the IBA treatment, since this phytoregulator can play a specific and direct role in establishing symbioses between fungi and plant roots, as well as stimulating the fungus to lateral root formation in the host (Etemadi et al., 2014). Apart from the application of synthetic auxin, natural plant auxin play essential role as signals during the establishment of AMF symbiosis particularly for the development of lateral roots which are the preferred infection sites for the fungi (LudwigMuller and Guther, 2007). On the other hand, the addition of PGPR enhance the availability and uptake of plant nutrients, the production of growth promoting substances and the suppression of deleterious bacteria which might have encouraged the 
rooted layers to put on better root and vegetative growth and hence an increase in plant height (Chawla, 2011).

The interaction effects between IBA and beneficial microorganism showed that the earliest root appearance and the best root and vegetative growth characteristics were obtained from combined IBA at $3000 \mathrm{ppm}$ by painting girdled zone with $B$. subtilis, followed by the same IBA treatment
+ AMF. These results are consistent with the findings of Rinallo et al. (1999), Scagel et al. (2003), ElNashar (2008), Abdel-Rahman and El-Naggar (2014). Yasser (2015) and Abdul Hakim et al. (2018) showed that combination of auxins with beneficial microorganisms significantly increased root and shoot characteristics of Punica granatum cuttings compared with the control.

Table 2. Number of days to emerge visual roots in Ficus elastica var. decora airlayers as affected by IBA treatments and beneficial microorganisms during the 2016 and 2017 seasons.

\begin{tabular}{|c|c|c|c|c|c|c|c|c|c|}
\hline \multirow{3}{*}{\multicolumn{2}{|c|}{$\begin{array}{c}\text { IBA } \\
\text { application methods } \\
\text { "ppm" }\end{array}$}} & \multicolumn{8}{|c|}{ Beneficial microorganisms } \\
\hline & & \multicolumn{4}{|c|}{ First season (2016) } & \multicolumn{4}{|c|}{ Second season (2017) } \\
\hline & & Cont. & Bacillus & AMF & Mean & Cont. & Bacillus & AMF & Mean \\
\hline \multicolumn{2}{|c|}{ Control (non-treated) } & 51.7 & 44.0 & 45.7 & 47.1 & 53.0 & 42.7 & 43.7 & 46.4 \\
\hline \multirow{2}{*}{ In the substrate } & 50 & 43.3 & 39.7 & 40.7 & 41.2 & 41.7 & 38.0 & 39.7 & 39.8 \\
\hline & 100 & 41.0 & 37.0 & 39.3 & 39.1 & 39.7 & 36.0 & 37.3 & 37.7 \\
\hline \multirow[b]{2}{*}{ By painting } & 1500 & 38.3 & 35.0 & 36.3 & 36.6 & 36.3 & 34.7 & 34.3 & 35.1 \\
\hline & 3000 & 36.3 & 31.0 & 33.7 & 33.7 & 35.0 & 30.3 & 33.3 & 32.9 \\
\hline \multirow[b]{2}{*}{ Talc paste } & 1500 & 38.7 & 36.0 & 37.3 & 37.3 & 37.3 & 34.7 & 35.7 & 35.9 \\
\hline & 3000 & 37.0 & 33.0 & 34.3 & 34.8 & 35.3 & 32.7 & 34.0 & 34.0 \\
\hline \multicolumn{2}{|l|}{ Mean } & 40.9 & 36.5 & 38.2 & & 39.8 & 35.6 & 36.9 & \\
\hline \multicolumn{2}{|l|}{ LSD at 0.05} & & & & & & & & \\
\hline \multicolumn{2}{|l|}{ IBA Treatments } & \multicolumn{4}{|c|}{1.3} & \multicolumn{4}{|c|}{1.1} \\
\hline \multirow{2}{*}{\multicolumn{2}{|c|}{ Microorganisms }} & \multirow{2}{*}{\multicolumn{4}{|c|}{0.6}} & \multicolumn{4}{|c|}{0.5} \\
\hline & & 1.6 & & & & \multicolumn{4}{|c|}{1.4} \\
\hline
\end{tabular}

Cont. $=$ control, AMF $=$ Arbuscular Mycorrhizal Fungi, Bacillus $=$ Bacillus subtilis

Table 3. Root number per air-layer of Ficus elastica var. decora as affected by IBA treatments and beneficial microorganisms during the 2016 and 2017 seasons.

\begin{tabular}{|c|c|c|c|c|c|c|c|c|c|}
\hline \multirow{3}{*}{\multicolumn{2}{|c|}{$\begin{array}{c}\text { IBA } \\
\text { application methods } \\
\text { "ppm" }\end{array}$}} & \multicolumn{8}{|c|}{ Beneficial microorganisms } \\
\hline & & \multicolumn{4}{|c|}{ First season (2016) } & \multicolumn{4}{|c|}{ Second season (2017) } \\
\hline & & Cont. & Bacillus & AMF & Mean & Cont. & Bacillus & AMF & Mean \\
\hline \multicolumn{2}{|c|}{ Control (non-treated) } & 7.68 & 13.67 & 11.50 & 10.95 & 10.67 & 12.33 & 12.00 & 11.67 \\
\hline \multirow{2}{*}{ In the substrate } & 50 & 9.73 & 19.44 & 18.33 & 15.84 & 12.50 & 15.50 & 14.67 & 14.22 \\
\hline & 100 & 9.89 & 20.77 & 19.44 & 16.70 & 14.00 & 19.50 & 19.33 & 17.61 \\
\hline \multirow{2}{*}{ By painting } & 1500 & 15.67 & 24.67 & 23.67 & 21.33 & 14.33 & 22.57 & 19.50 & 18.80 \\
\hline & \begin{tabular}{|l|}
3000 \\
\end{tabular} & 23.13 & 26.17 & 27.67 & 25.65 & 17.50 & 26.67 & 24.67 & 22.94 \\
\hline \multirow{2}{*}{ Talc paste } & 1500 & 16.20 & 21.47 & 19.77 & 19.14 & 14.83 & 19.83 & 18.00 & 17.56 \\
\hline & 3000 & 16.00 & 24.43 & 23.33 & 21.26 & 15.17 & 22.00 & 19.00 & 18.72 \\
\hline \multicolumn{2}{|l|}{ Mean } & 14.04 & 21.52 & 20.53 & & 14.14 & 19.77 & 18.17 & \\
\hline \multicolumn{2}{|l|}{ LSD at 0.05} & & & & & & & & \\
\hline \multicolumn{2}{|l|}{ IBA Treatments } & \multicolumn{4}{|c|}{1.67} & \multicolumn{4}{|c|}{1.50} \\
\hline \multirow{2}{*}{\multicolumn{2}{|c|}{ Microorganisms }} & \multirow{2}{*}{\multicolumn{4}{|c|}{0.82}} & \multicolumn{4}{|c|}{0.71} \\
\hline & & & & & 2.18 & \multicolumn{4}{|c|}{1.87} \\
\hline
\end{tabular}

Cont. $=$ control, $\mathrm{AMF}=$ Arbuscular Mycorrhizal Fungi, Bacillus $=$ Bacillus subtilis 
Table 4. Root length (cm) per air-layer of Ficus elastica var. decora as affected by IBA treatments and beneficial microorganisms during the 2016 and 2017 seasons.

\begin{tabular}{|c|c|c|c|c|c|c|c|c|c|}
\hline \multirow{3}{*}{\multicolumn{2}{|c|}{$\begin{array}{c}\text { IBA } \\
\text { application methods } \\
\text { "ppm" }\end{array}$}} & \multicolumn{8}{|c|}{ Beneficial microorganisms } \\
\hline & & \multicolumn{4}{|c|}{ First season (2016) } & \multicolumn{4}{|c|}{ Second season (2017) } \\
\hline & & Cont. & Bacillus & AMF & Mean & Cont. & Bacillus & AMF & Mean \\
\hline \multicolumn{2}{|c|}{ Control (non-treated) } & 8.90 & 11.83 & 10.87 & 10.54 & 10.17 & 13.33 & 13.00 & 12.17 \\
\hline \multirow{2}{*}{ In the substrate } & 50 & 11.83 & 16.11 & 14.33 & 14.09 & 13.83 & 16.67 & 15.17 & 15.22 \\
\hline & 100 & 12.33 & 17.44 & 14.67 & 14.81 & 14.50 & 18.00 & 14.50 & 15.67 \\
\hline \multirow{2}{*}{ By painting } & 1500 & 14.78 & 18.33 & 17.33 & 16.81 & 15.67 & 19.50 & 17.33 & 17.50 \\
\hline & 3000 & 16.17 & 21.00 & 18.67 & 18.61 & 17.67 & 22.17 & 21.67 & 20.50 \\
\hline \multirow{2}{*}{ Talc paste } & 1500 & 12.62 & 16.50 & 15.87 & 15.00 & 14.83 & 16.50 & 17.17 & 16.17 \\
\hline & 3000 & 14.53 & 17.23 & 17.17 & 16.31 & 16.33 & 18.17 & 18.67 & 17.72 \\
\hline \multicolumn{2}{|l|}{ Mean } & 13.02 & 16.92 & 15.56 & & 14.71 & 17.76 & 16.79 & \\
\hline \multicolumn{10}{|l|}{\begin{tabular}{|l|} 
LSD at 0.05 \\
\end{tabular}} \\
\hline \multicolumn{2}{|c|}{ IBA Treatments } & \multicolumn{4}{|c|}{0.43} & \multicolumn{4}{|c|}{0.47} \\
\hline \multicolumn{2}{|l|}{\begin{tabular}{|l} 
Microorganisms \\
\end{tabular}} & \multicolumn{4}{|c|}{0.33} & \multicolumn{4}{|c|}{0.36} \\
\hline \multicolumn{2}{|l|}{ Interaction } & \multicolumn{4}{|c|}{0.87} & \multicolumn{4}{|c|}{0.96} \\
\hline
\end{tabular}

Cont $=$ control, AMF $=$ Arbuscular Mycorrhizal Fungi, Bacillus $=$ Bacillus subtilis

Table 5. Root fresh weight (g/air-layer) of Ficus elastica var. decora as affected by IBA treatments and beneficial microorganisms during the 2016 and 2017 seasons.

\begin{tabular}{|c|c|c|c|c|c|c|c|c|c|}
\hline \multirow{3}{*}{\multicolumn{2}{|c|}{$\begin{array}{c}\text { IBA } \\
\text { application methods } \\
\text { "ppm" }\end{array}$}} & \multicolumn{8}{|c|}{ Beneficial microorganisms } \\
\hline & & \multicolumn{4}{|c|}{ First season (2016) } & \multicolumn{4}{|c|}{ Second season (2017) } \\
\hline & & Cont. & Bacillus & AMF & Mean & Cont. & Bacillus & AMF & Mean \\
\hline \multicolumn{2}{|c|}{ Control (non-treated) } & 3.93 & 7.90 & 6.83 & 6.22 & 4.49 & 7.25 & 6.33 & 6.02 \\
\hline \multirow{2}{*}{ In the substrate } & 50 & 8.33 & 14.93 & 14.67 & 12.64 & 7.60 & 14.10 & 12.67 & 11.46 \\
\hline & 100 & 8.40 & 17.60 & 16.00 & 14.00 & 9.52 & 16.91 & 16.05 & 14.16 \\
\hline \multirow{2}{*}{ By painting } & 1500 & 9.30 & 22.00 & 19.00 & 16.77 & 10.66 & 19.42 & 17.63 & 15.90 \\
\hline & 3000 & 15.93 & 23.00 & 22.33 & 20.42 & 13.50 & 23.81 & 19.67 & 18.99 \\
\hline \multirow{2}{*}{ Talc paste } & 1500 & 9.20 & 18.70 & 16.90 & 14.93 & 9.89 & 17.86 & 17.14 & 14.96 \\
\hline & 3000 & 11.17 & 21.10 & 20.00 & 17.42 & 12.30 & 19.74 & 18.07 & 16.70 \\
\hline \multicolumn{2}{|l|}{ Mean } & 9.47 & 17.89 & 16.53 & & 9.71 & 17.01 & 15.36 & \\
\hline \multicolumn{10}{|l|}{ LSD at 0.05} \\
\hline \multicolumn{2}{|l|}{ IBA Treatments } & \multicolumn{4}{|c|}{0.77} & \multicolumn{4}{|c|}{1.27} \\
\hline \multicolumn{2}{|l|}{ Microorganisms } & \multicolumn{4}{|c|}{0.74} & \multicolumn{4}{|c|}{0.85} \\
\hline \multicolumn{2}{|l|}{ Interaction } & \multicolumn{4}{|c|}{1.95} & \multicolumn{4}{|c|}{2.26} \\
\hline
\end{tabular}

Cont. $=$ control, $\mathrm{AMF}=$ Arbuscular Mycorrhizal Fungi, Bacillus $=$ Bacillus subtilis

Table 6. Root dry weight (g/air-layer) of Ficus elastica var. decora as affected by IBA treatments and beneficial microorganisms during the 2016 and 2017 seasons.

\begin{tabular}{|c|c|c|c|c|c|c|c|c|c|}
\hline \multirow{3}{*}{\multicolumn{2}{|c|}{$\begin{array}{c}\text { IBA } \\
\text { application methods } \\
\text { "ppm" }\end{array}$}} & \multicolumn{8}{|c|}{ Beneficial microorganisms } \\
\hline & & \multicolumn{4}{|c|}{ First season (2016) } & \multicolumn{4}{|c|}{ Second season (2017) } \\
\hline & & Cont. & Bacillus & AMF & Mean & Cont. & Bacillus & AMF & Mean \\
\hline \multicolumn{2}{|c|}{ Control (non-treated) } & 1.63 & 3.29 & 3.03 & 2.65 & 1.89 & 3.19 & 3.12 & 2.73 \\
\hline \multirow{2}{*}{ In the substrate } & 50 & 3.37 & 4.32 & 4.32 & 4.01 & 3.34 & 4.29 & 4.16 & 3.93 \\
\hline & 100 & 3.67 & 4.69 & 4.37 & 4.24 & 3.40 & 4.64 & 4.41 & 4.15 \\
\hline \multirow{2}{*}{ By painting } & 1500 & 3.70 & 5.58 & 4.90 & 4.73 & 3.89 & 5.17 & 4.46 & 4.51 \\
\hline & 3000 & 4.68 & 5.66 & 5.39 & 5.24 & 4.05 & 5.91 & 5.18 & 5.05 \\
\hline \multirow{2}{*}{ Talc paste } & 1500 & 3.58 & 4.63 & 4.03 & 4.08 & 3.55 & 4.90 & 4.41 & 4.29 \\
\hline & 3000 & 3.84 & 4.92 & 4.92 & 4.56 & 4.00 & 5.43 & 5.00 & 4.81 \\
\hline \multicolumn{2}{|l|}{ Mean } & 3.50 & 4.73 & 4.42 & & 3.45 & 4.79 & 4.39 & \\
\hline \multicolumn{10}{|l|}{ LSD at 0.05} \\
\hline \multicolumn{2}{|c|}{ IBA Treatments } & \multicolumn{4}{|c|}{0.42} & \multicolumn{4}{|c|}{0.41} \\
\hline \multicolumn{2}{|l|}{ Microorganisms } & \multicolumn{4}{|c|}{0.31} & \multicolumn{4}{|c|}{0.26} \\
\hline \multicolumn{2}{|l|}{ Interaction } & \multicolumn{4}{|c|}{ N.S. } & \multicolumn{4}{|c|}{ N.S. } \\
\hline
\end{tabular}

Cont $=$ control, $\mathrm{AMF}=$ Arbuscular Mycorrhizal Fungi, Bacillus $=$ Bacillus subtilis 
IBA application methods and its concentrations
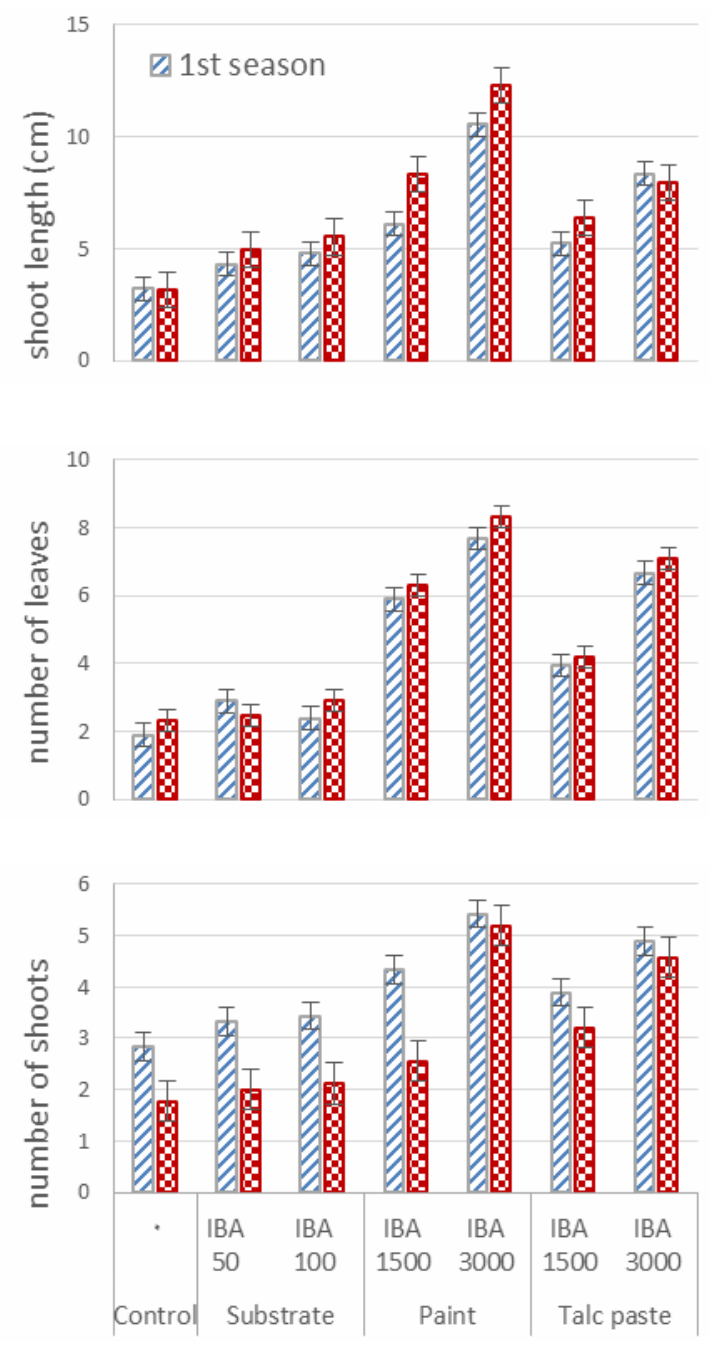

Beneficial microorganisms
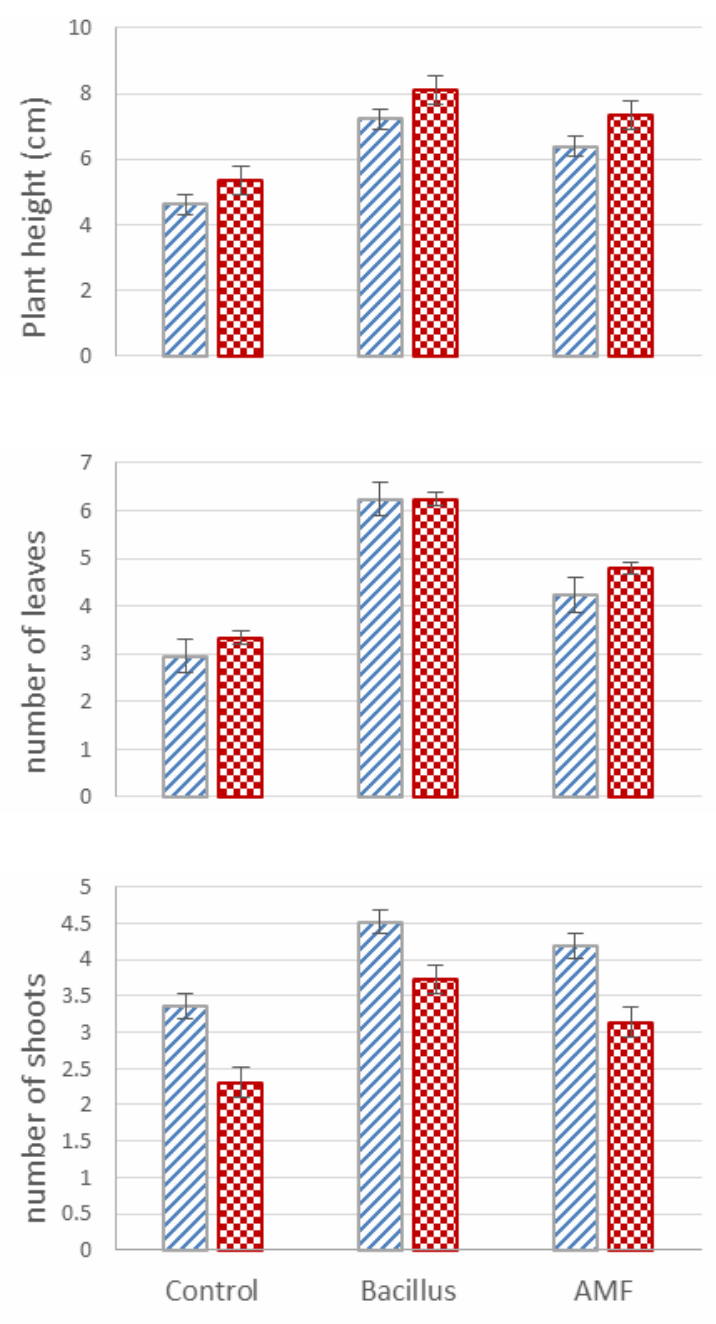

Fig. 1. Effect of IBA at different concentrations and application methods and beneficial microorganisms on vegetative growth characteristics of $F$. elastica var. decora during both seasons. Vertical bars above mean denote LSD values $(p \leq 0.05)$. 


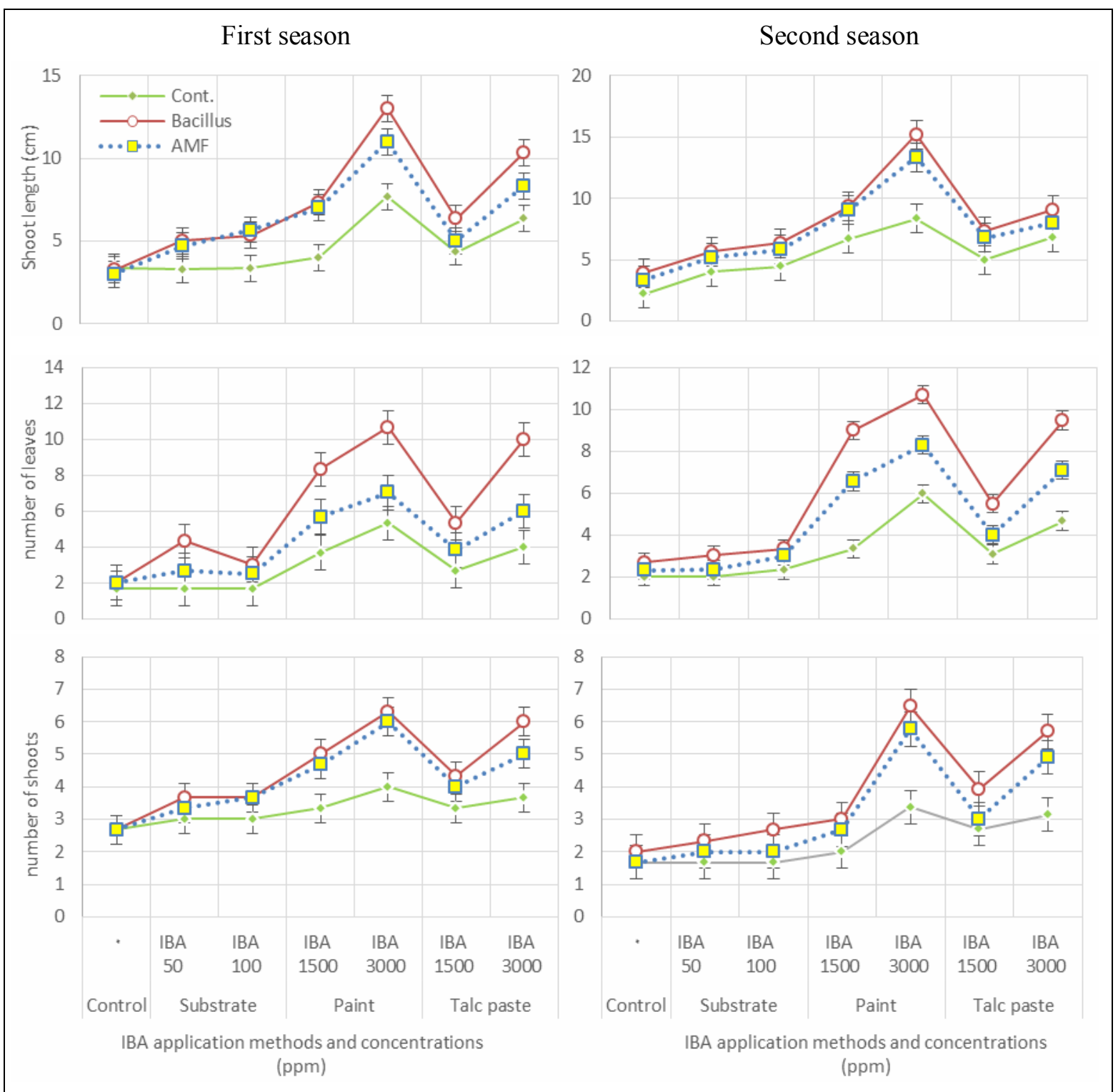

Fig. 2. Interaction effects between IBA at different concentrations and application methods and beneficial microorganisms on vegetative growth characteristics of $F$. elastica var. decora during both seasons. Vertical bars above mean denote LSD values $(p \leq 0.05)$.

\section{Survival percentage}

Data presented in Table 7 show that the best treatments which improved root and shoot characteristics, also enhanced survival percentage of successfully rooted air-layers. Generally, treating air-layers with IBA at $3000 \mathrm{ppm}$ by painting girdled zone combined with Bacillus or AMF produced the best survival percentage $(100 \%)$ in both seasons comparing to ca. $50 \%$ in untreated layers (control) as an average of both seasons (Table
$7)$. These results are in agreement with the finding of Kumar (2011), Chawla (2011) and Khalid et al. (2004). Improvement in root and vegetative growth characteristics by the combined treatment of $3000 \mathrm{ppm}$ IBA with the beneficial microorganisms could explain the percentage of survival after transplanting derived by the same treatment (Kumar, 2011 and Yasser, 2015). In addition, beneficial microorganisms including bacteria and mycorrhizal fungi has a 
great role in promoting better uptake of water and nutrients by the plant and hence improving survival per-

Table 7. Survival percentage of new produced plants after 6 months from transplanting in Ficus elastica var. decora as affected by IBA treatments and beneficial microorganisms during the 2016 and 2017 seasons.

\begin{tabular}{|c|c|c|c|c|c|c|c|c|c|}
\hline \multirow{3}{*}{\multicolumn{2}{|c|}{$\begin{array}{l}\text { IBA } \\
\text { application methods } \\
\text { "ppm" }\end{array}$}} & \multicolumn{8}{|c|}{ Beneficial microorganisms } \\
\hline & & \multicolumn{4}{|c|}{ First season (2016) } & \multicolumn{4}{|c|}{ Second season (2017) } \\
\hline & & Cont. & Bacillus & AMF & Mean & Cont. & Bacillus & AMF & Mean \\
\hline \multicolumn{2}{|c|}{ Control (non-treated) } & 50.03 & 50.00 & 50.00 & 50.01 & 50.03 & 50.00 & 50.00 & 50.01 \\
\hline \multirow{2}{*}{ In the substrate } & 50 & 61.10 & 77.77 & 72.23 & 70.37 & 61.10 & 77.77 & 72.23 & 70.37 \\
\hline & 100 & 66.67 & 88.90 & 88.90 & 81.49 & 77.77 & 88.90 & 88.90 & 85.19 \\
\hline \multirow{2}{*}{ By painting } & 1500 & 72.23 & 88.90 & 77.80 & 79.64 & 72.23 & 77.80 & 77.80 & 75.94 \\
\hline & 3000 & 77.80 & 100.00 & 92.00 & 89.93 & 77.80 & 100.00 & 91.67 & 89.82 \\
\hline \multirow{2}{*}{ Talc paste } & 1500 & 66.67 & 77.80 & 77.80 & 74.09 & 66.67 & 77.80 & 77.80 & 74.09 \\
\hline & 3000 & 77.80 & 91.67 & 88.90 & 86.12 & 77.80 & 91.67 & 88.90 & 86.12 \\
\hline \multicolumn{2}{|l|}{ Mean } & 67.47 & 82.15 & 78.23 & & 69.06 & 80.56 & 78.19 & \\
\hline \multicolumn{10}{|l|}{ LSD at 0.05} \\
\hline \multicolumn{2}{|l|}{ IBA Treatments } & \multicolumn{4}{|c|}{1.13} & \multicolumn{4}{|c|}{4.46} \\
\hline \multirow{2}{*}{\multicolumn{2}{|c|}{ Microorganisms }} & \multirow{2}{*}{\multicolumn{4}{|c|}{$\begin{array}{ll}0.94 \\
2.48\end{array}$}} & \multicolumn{4}{|c|}{2.32} \\
\hline & & & & & & \multicolumn{4}{|c|}{6.13} \\
\hline
\end{tabular}

\section{Total carbohydrates and phenols content}

The results presented in Tables 8 and 9 show that the combination of IBA with beneficial microorganisms significantly increased content of total carbohydrates and phenols in layered shoots tissues compared to untreated layers. The highest contents of total carbohydrates and phenols were obtained by treating air-layers with $3000 \mathrm{ppm}$ IBA by painting girdled zone $+B$. subtilis, followed by the same IBA treatment + AMF. The increment in polyphenolic compounds produced by IBA plus $B$. subtilis or AMF has a direct role in decreasing auxin oxidation and accordingly improve rootability as well as root and shoot characteristics (Mitchell et al., 1986 and Scagel and Linderman, 1998). Also, this might be due to that the monophenol can increase root growth as the enzyme polyphenol oxidase can induce second $\mathrm{OH}$ group in to the ring of a monophenol centage (Kumar and Syamal, 2005 and Cakmakci et al, 2006).
(Goodwin, 1976) and convert it into diphenol, this in turn induces better rooting (Kunal and Syamal, 2005). Phenolic compounds are shown to interact with proteins leading to altered metabolism form roots in airlayers (Kefeli and Kutacek, 1976).

As for carbohydrates, it has been suggested that auxincarbohydrates are important in regulating root formation (Hansen et al., 1978, Abdel-Rahman and ElDosouky, 2010 and Chawla, 2011). Arslonov (1979) reported that the exogenous application of auxins resulted in the utilization of the stored food substances for quicker root formation. It is assumed that some substances in addition to auxins as carbohydrates are produced in leaves and transported to the rooting zone which enhance the rooting process (Raviv and Reuveni, 1984). Carbohydrates may function solely as a source of metabolic fuel which is necessary to provide the energy 
needed for root formation. Carbohydrates may also influence the auxin status thereby influencing adventitious root formation. In this regard, it has been suggested that auxin synthesis or transport is linked to the supply of photosynthate since conditions which reduced photosynthesis also reduced endogenous auxin levels (Vardar, 1968). In addition, the increase in carbohydrates content in bases of layered shoots in F. elastica var. decora as a result of the inoculation with $B$. subtilis or AMF may be due to the production of IAA by beneficial microorganisms, which stimulated adventitious root formation, and resulted in better absorption of water and nutrients from the soil as well as increasing of vegetative growth. Reuveni and Raviv (1981) found a positive correlation among carbohydrates content, growth promoters and the rooting response. Abdel Rahman and El-Dsouky (2010) indicated that application of IBA in combination with $B$. subtilis was more effective treatment in increasing carbohydrates content in cutting bases when compared to the control, or IBA and/or B. subtilis alone.

Table 8. Total carbohydrates (\%) in tissue of girdled zone in Ficus elastica var. decora as affected by IBA treatments and beneficial microorganisms during the 2016 and 2017 seasons.

\begin{tabular}{|c|c|c|c|c|c|c|c|c|c|}
\hline \multirow{3}{*}{\multicolumn{2}{|c|}{$\begin{array}{c}\text { IBA } \\
\text { application methods } \\
\text { "ppm" }\end{array}$}} & \multicolumn{8}{|c|}{ Beneficial microorganisms } \\
\hline & & \multicolumn{4}{|c|}{ First season (2016) } & \multicolumn{4}{|c|}{ Second season (2017) } \\
\hline & & Cont. & Bacillus & AMF & Mean & Cont. & Bacillus & AMF & Mean \\
\hline \multicolumn{2}{|c|}{ Control (non-treated) } & 15.93 & 19.17 & 18.14 & 17.75 & 18.13 & 19.33 & 18.51 & 18.66 \\
\hline \multirow{2}{*}{ In the substrate } & 50 & 19.01 & 22.06 & 20.79 & 20.62 & 18.97 & 20.86 & 19.57 & 19.80 \\
\hline & 100 & 19.86 & 23.03 & 20.00 & 20.96 & 19.34 & 22.40 & 20.70 & 20.81 \\
\hline \multirow{2}{*}{ By painting } & 1500 & 21.40 & 22.94 & 23.17 & 22.50 & 20.00 & 23.03 & 23.73 & 22.26 \\
\hline & 3000 & 19.86 & 23.85 & 25.21 & 22.97 & 20.47 & 25.20 & 25.73 & 23.80 \\
\hline \multirow{2}{*}{ Talc paste } & 1500 & 19.43 & 21.92 & 21.14 & 20.83 & 19.33 & 21.79 & 21.33 & 20.82 \\
\hline & 3000 & 22.31 & 23.40 & 23.47 & 23.06 & 21.83 & 23.40 & 23.70 & 22.98 \\
\hline \multicolumn{2}{|l|}{ Mean } & 19.69 & 22.34 & 21.70 & & 19.73 & 22.29 & 21.90 & \\
\hline \multicolumn{10}{|l|}{ LSD at 0.05} \\
\hline \multicolumn{2}{|l|}{ IBA Treatments } & \multicolumn{4}{|c|}{0.30} & \multicolumn{4}{|c|}{1.02} \\
\hline \multicolumn{2}{|l|}{ Microorganisms } & \multicolumn{4}{|c|}{0.36} & \multicolumn{4}{|c|}{0.65} \\
\hline \multicolumn{2}{|l|}{ Interaction } & \multicolumn{4}{|c|}{0.95} & \multicolumn{4}{|c|}{1.73} \\
\hline
\end{tabular}

Table 9. Total phenolics (mg GAE/ g DW) in tissue of girdled zone in Ficus elastica var. decora as affected by IBA treatments and beneficial microorganisms during the 2016 and 2017 seasons.

\begin{tabular}{|c|c|c|c|c|c|c|c|c|c|}
\hline \multirow{3}{*}{\multicolumn{2}{|c|}{$\begin{array}{c}\text { IBA } \\
\text { application methods } \\
\text { "ppm" }\end{array}$}} & \multicolumn{8}{|c|}{ Beneficial microorganisms } \\
\hline & & \multicolumn{4}{|c|}{ First season (2016) } & \multicolumn{4}{|c|}{ Second season (2017) } \\
\hline & & Cont. & Bacillus & AMF & Mean & Cont. & Bacillus & AMF & Mean \\
\hline \multicolumn{2}{|c|}{ Control (non-treated) } & 12.70 & 15.73 & 10.80 & 13.08 & 13.47 & 17.00 & 10.80 & 13.76 \\
\hline \multirow{2}{*}{ in the substrate } & 50 & 13.10 & 16.83 & 16.60 & 15.51 & 14.70 & 18.13 & 17.00 & 16.61 \\
\hline & 100 & 15.70 & 19.10 & 14.78 & 16.53 & 16.90 & 20.83 & 15.55 & 17.76 \\
\hline \multirow{2}{*}{ by painting } & 1500 & 17.70 & 20.90 & 15.00 & 17.87 & 18.30 & 22.20 & 15.63 & 18.71 \\
\hline & 3000 & 20.30 & 20.97 & 23.17 & 21.48 & 19.40 & 21.57 & 24.17 & 21.71 \\
\hline \multirow{2}{*}{ Talc paste } & 1500 & 17.80 & 20.10 & 18.53 & 18.81 & 17.33 & 22.33 & 21.00 & 20.22 \\
\hline & 3000 & 19.97 & 23.53 & 17.20 & 20.23 & 17.73 & 25.07 & 17.80 & 20.20 \\
\hline \multicolumn{2}{|l|}{ Mean } & 16.75 & 19.60 & 16.58 & & 16.83 & 21.02 & 17.42 & \\
\hline \multicolumn{2}{|l|}{ LSD at 0.05} & & & & & & & & \\
\hline \multicolumn{2}{|l|}{ IBA Treatments } & \multicolumn{4}{|c|}{0.59} & \multicolumn{4}{|c|}{0.87} \\
\hline \multicolumn{2}{|l|}{ Microorganisms } & \multicolumn{4}{|c|}{0.36} & \multicolumn{4}{|c|}{0.43} \\
\hline \multicolumn{2}{|l|}{ Interaction } & \multicolumn{4}{|c|}{0.94} & \multicolumn{4}{|c|}{1.13} \\
\hline
\end{tabular}

Cont. $=$ control, AMF $=$ Arbuscular Mycorrhizal Fungi, Bacillus $=$ Bacillus subtilis 


\section{Promoters and inhibitors}

GC MS analysis (Fig. 3) of two samples extracted from rooting zone of the air-layers for the control and best treatment for improving rooting and survival percentages, as well as root and shoot characteristics (IBA at 3000 ppm by painting girdled zone + B. subtilis) showed the presence of only 2 constituents (indole acetic acid and its derivatives at $20.9 \%$ and zeatin at $0.28 \%$ ) in control and 3 ones (indole acetic acid and its derivatives at $22.9 \%$, zeatin at $0.06 \%$ and longiborneol as flavonol at $1.65 \%$ as a percentage of total organic compounds per sample). The present results showed that there was a positive relationship between the best rooting and survival percentages, as well as root and vegetative growth characteristics and the high concentration of indole acetic acid and its derivatives obtained by the best treatment of 3000 ppm IBA by painting girdled zone plus $B$. subtilis comparing to the control. The promotive effects of $\mathrm{IBA}+$ B. subtilis combined treatment in adventitious root formation could be attributed to the increase in IAA production by B. subtilis (Goto, 1990). On the other hand, Maldiney et al. (1986) found that increasing cytokinins appear to have inhibitory effects on adventitious root formation and they reported a change in their levels during root initiation. As for gibberellic acid, some investigators reported inhibitory effects of $\mathrm{GA}_{3}$ on adventitious root formation and number of roots (Kato, 1958, Bostrack and Struckmeyer, 1967 and Mauriat et al., 2014).

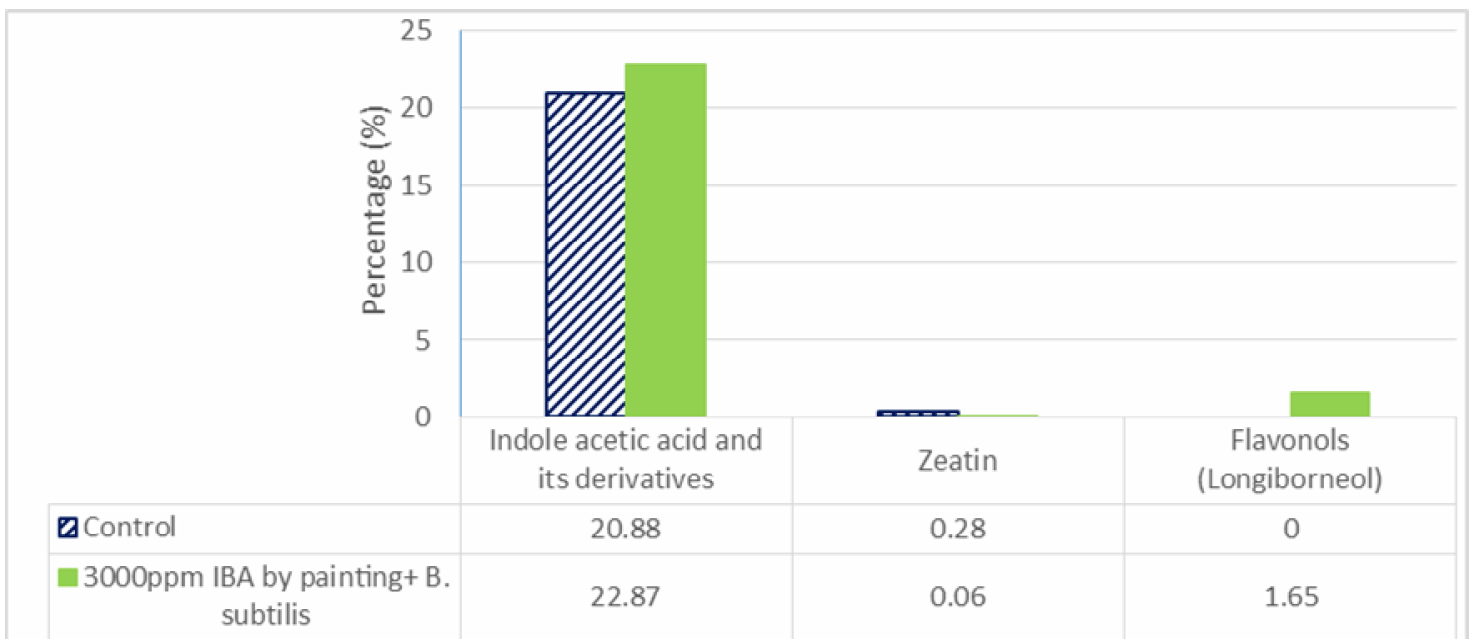

Fig. 3. GC-MS analysis of two samples extracted from root zone of Ficus eleastics var. decora layers treated with IBA at 3000 ppm by painting girdled zone + B. subtilis and the control.

\section{Conclusions}

From the above mentioned results, it appears that all treatments tested significantly increased rooting and survival percentages, as well as root and shoot characteristics compared to the control. The best results were obtained from treatment of air- layers with 3000 ppm IBA by painting girdled zone combined with $B$. subtilis, followed by the same IBA treatment + AMF. Hence, this treatment is recommended for improving the propagation of $F$. elastica var. decora through air layering. 


\section{References}

Abdel-Rahman, S.S.A. and A.I. ElNaggar (2014). Promotion of rooting and growth of some types of Bougainvilleas cutting by plant growth promoting rhizobacteria (PGPR) and arbuscular mycorrhizal fungi (AMF) in combination with indole-3-butyricacid (IBA). International Journal of Science and Research, 3(11): 97-108.

Abdel-Rahman, S.S.A. and M. ElDsouky (2010). Effect of indole-3butyric acid (IBA) and Bacillus subtilis on rooting of Bougainvillea glabra var. sanderiana cuttings. The $5^{\text {th }}$ Scientific Conference for Agricultural Sciences, Fac. Agric. Assiut Univ. Oct. 1617, pp. 51-71.

Abdul Hakim, S.; M.K. Jaganath; S.M. Honnabyraiah; S.A. Kumar and K.J. Dayamani (2018). Influence of biofertilizer and auxin on growth and rooting of pomegranate (Punica granatum L.) cuttings. Int. J. Curr. Microbiol. App. Sci., 7(2): 1187-1193.

Amissah, J.N.; D.J. Paolillo Jr. and N. Bssuk (2008). Advintitous root formation in stem cuttings of Quercus bicolor and Quercus marocarpa and its relationship to stem anatomy. J. Amer. Soci. Hort. Sci., 133(4): 479-486.

Arslonov, M.N. (1979). Physiological changes occuring during root formation in lemon cuttings. Uzabekskii Biologicheskii Zhurnal, 5: 24-26.

Baghel, M.; U.A. Raut and V. Ramteke (2016). Effect of IBA concentrations and time of air-layering in guava cv. L-49. Research Journal of Agricultural Sciences, 7(1): 117-120.

Baily, L.H. (1963). The Standard Cyclopedia of Horticulture. $2^{\text {nd }}$ Edn.
1229-1233.: The MacMillan Publishing Company, New York.

Balota, E.L.; O. Machineski and N.M.C. Stenzel (2011). Resposta da acerola à inoculação de fungos micorrízicos arbusculares em solo com diferentes níveis de fósforo. Bragantia, 70: 166-175.

Barea, J.M. and C. Azcon-Aguilar (1982). Production of plant growth regulating substances by the vesicular arbuscular mycorrhizal fungus Glomus mosseae. Appl. Envl. Micro., 43: 810-813.

Bostrack, J.M. and B.E. Struckmeyer (1967). Effect of gibberellic acid on the growth and anatomy of $\mathrm{Co}$ leus blumei, Antirrhinum majus and Salvia splendens. New Phytol., 66: 539-544.

Cakmakci, R.; F. Donmez; A. Aydin and F. Sahin (2006). Growth promotion of plants by plant growthpromoting rhizobacteria under greenhouse and two different field soil condition. Soil Biology Biochem., 38: 1482-1487.

Cameron, R.J. and G.L. Thompson (1969). The vegetative propagation of Pinus radiata :- root initiation in cuttings. Hort. Gaz. 130(4):242251.

Chawla, W. (2011). Studies on air layering, survival and growth of rooted layers in litchi (Litchi chinensis Sonn.). M.Sc. Thesis, College of Horticulture Dr Yashwant Singh Parmar University of Horticulture and Forestry, Nauni, Solan, India. http://krishikosh.egranth.ac.in/bitst ream/1/5810001296/1/Wineet $\% 20$ Chawla.pdf

Chovatia, R.S. and S.P. Singh (2000). Success of air-layering in custard apple (Annona squamosa L.) as influenced by hinging of shoots and growth regulators. The Orissa J. Hort., 28 (2): 61-65. 
Clark, S.L.; S.E. Scblarbaum and P.P. Kormanik (2000). Visual grading and quality of 1-0 Northern red oak seedlings. Southern J. Applied For., 24: 93-97.

Dessalegn, Y. and Y.N. Reddy (2003). Effects of different concentrations of auxins on rooting and root characters of air and ground layers of jojoba (Simmondsia chinensis (LINK.) C. K. Schneider). Ethiop. J. Sci., 26(2):155-159.

Dharshan, B.V. (2008). Studies on propagation through stem cuttings and air layering in fig (Ficus carica L.) cultivar Poona Fig. M.Sc. Thesis, Division of Horticulture, University of Agricultural Sciences, Bangalore.

http://krishikosh.egranth.ac.in/bitst ream/1/5810025160/1/Th-9265.pdf

El-Nashar, M.F. (2008). Application of auxin, vitamins and bacteria to hard to root cuttings for commercial production of two ornamental shrubs. Ph.D. Thesis, Fac. Agric., Assiut Univ., Egypt.

Ercisli, S., A. Esitken and F. Sahin (2004). Exogenous IBA and inoculation with Agrobacterium rubi stimulate adventitious root formation on hardwood stem cuttings of two rose genotypes. HortScience., 39(3): 533-534.

Erturk, Y.; S. Ercisli; A. Haznedar and R. Cakmakci (2010). Effects of plant growth promoting rhizobacteria (PGPR) on rooting and root growth of kiwifruit (Actinidia deliciosa) stem cuttings. Biol. Res., 43: 91-98.

Esitken, A.; S. Ercisli; D. Sevik and F. Sahin (2003). Effect of indole-3butyric acid and different strains of Agrobacterium rubi on adventive root formation from softwood and semi-hardwood wild sour cherry cuttings. Turkish Journal of Agriculture and Forestry, 27: 37-42.

Etemadi, M.; C. Gutjahr; J.M. Couzigoou; M. Zouine; D. Lauressergues; A. Timmers; C. Audran; M. Bouzayen; G. Bécard and J.P. Combier (2014). Auxin perception is required for arbuscule development in arbuscular mycorrhizal symbiosis. Plant Physiology, 166: 281-292.

Fales, F.W. (1951). The assimilation and degradation of carbohydrates by yeast cells. J. Bio. Chem., 193213.

Gamlath, M.; K. Abeywickrama and S. Wickramarachchi (2010). Root growth promotion of Ficus species during air-layering. Cey. J. Sci. (Bio. Sci.), 39 (1): 45-51.

Ghosh, A.; K. Dey; A. Mani; F.K. Bauri and D.K. Mishra (2017). Efficacy of different levels of IBA and NAA on rooting of phalsa (Grewia asiatica L.) cuttings. International Journal of Chemical Studies, 5(6): 567-571.

Gilani, S.A.Q.; K. Shah; I. Ahmed; A. Basit; M. Sajid; A.S. Bano; G. Ara and U. Shahid (2019). Influence of indole butyric acid (IBA) concentrations on air layerage in guava (Psidium guajava L.) cv. Sufeda. Pure Appl. Biol., 8(1): 355-362.

Gomez, K.A. and A.A. Gomez (1984). Statistical Procedures for Agricultural Research. $2^{\text {nd }}$ edn. John Wily, NY, $680 \mathrm{pp}$

Goodwin, T.W. (1976). Chemistry and bio-chemistry of plant pigments. Vol. I, Academic Press, 736.

Goto, M. (1990). Fundamentals of Bacterial Plant Pathology. Academic Press. Inc. San Diego, 339 pp.

Hansen, J.; L.H. Strömquist and A. Ericsson (1978). Influnce of the irradiance on carbohydrate content and rooting of cuttings of pine 
seedlings (Pinus sylvestris L.). Plant Physiol.., 61: 975-979.

Hartmann, H.T.; D.E. Kester; F.T. Davies and R.L. Geneve (2011). Hartmann and Kester's Plant Propagation: Principles and Practices, $8^{\text {th }}$ ed. Prentice Hall, New Jersey (928 Pp.).

Kasem, M.M. and M.M. Abd El-Baset (2014). A comparative study to improve rooting of English lavender stems cuttings. Afri. J. of Agric. Res., 9(50): 3632-3637.

Kato, J. (1958). Studies on the physiological effect of gibberellin II. On the interaction of gibberellin with auxins and growth inhibitors. Physiologia PL, pp. 11-10.

Kefeli, V.I. and M. Kutacek (1976). Phenolic substances and their possible role in plant growth regulation (Ed.: P.E Pilet). Springervarlog, Berlin and New York, p. 181-182.

Khalid, A.; M. Arshad and Z.A. Zahir (2004). Screening plant growthpromoting rhizobacteria for improving growth and yield of wheat. Journal of Applied Microbiology, 96: 473-480.

Kumar, K. and M.M. Syamal (2005). Effect of etiolation and plant growth substances on rooting and survival of air layering of guava. Ind. J. Hort., 62: 290-292.

Kumar, S. (2011). Layering in guava as influenced by growth regulators and Azospirillum. M.Sc. Thesis, Department of Horticulture College of Agriculture, Dharward University of Agricultural Science, Dharwad (India).

http://krishikosh.egranth.ac.in/bitstream/ 1/85229/1/th10316.pdf

Kunal, K. and M.M. Syamal (2005). Effect of etiolation and plant growth substances on rooting and survival of air layering of guava. Ind. J. Hort., 62: 290-292.
Ludwig-Muller, J. and M. Guther (2007). Auxins as signals in arbuscular mycorrhiza formation. Plant Signal. Behav., 2: 194-196.

Lwin, K.M.; M.M. Myint; T. Tar and W.Z.M. Aung (2012). Isolation of plant hormones (IAA) producing rhizobacteria and study on their effect on maize seedling. Engin. J., 16(5): 137-144.

Maldiney, R.; F. Pelese; G. Pilate; B. Sotta; L. Sossountzov and E. Miginiac (1986). Endogenous levels of abscisic acid, indole-3-acetic acid, zeatin and zeatin-riboside during the course of adventitious root formation in cuttings of Craigella and Craigella lateral suppressor tomatoes. Physiol. Plant., 68: 426-430.

Maliauskas, G.; P.R. Venskutonis and T. A. Van Beek (2004). Screening of Radical Scavenging Activity of Some Medicinal and Aromatic Plants Extracts. Food Chem., 85: 231-237.

Mauriat, M.; A. Petterle; C. Bellini and T. Moritz (2014). Gibberellins inhibit adventitious rooting in hybrid aspen and Arabidopsis by affecting auxin transport. The Plant J., 78: 372-384.

McAfee, B.J.; E.E. White; L.E. Pelcher and M.S. Lapp (1993). Root induction in pine (Pinus) and larch (Larix) spp. using Agrobacterium rhizogenes. Plant cell Tiss. Organ culture, 34: 53-62.

Mitchell, R.J.; H.E. Garrett; G.S. Cox and A. Atalay (1986). Boron and ectomycorrhizal influences on indole-3-acetic acid levels and indole-3-acetic acid oxidase and peroxidase activities of Pinus echinata roots. Tree Physiol., 1:1-8.

Paul, R. and Ch. Aditi (2009): IBA and NAA of $1000 \mathrm{ppm}$ induce more improved rooting characters in airlayers of waterapple (Syzygium 
javanica L.). Bulgarian Journal of Agricultural Science, 15 (2): 123128.

Pirlak, L. (2009). Effect of IBA and bacteria (Agrobacterium rubi ve $B a$ cillus OSU 142) on the rooting of M9 apple rootstock cuttings. ${ }^{\text {st }}$ International Symposium on Sustainable Development, June 9-10 2009, Sarajevo129.

Porlingis, I.C.; M. Petridou and D.G. Voyiatzis (1999). An improved method of propagating the olive by mound-layering. Acta Hortculturae, 474: 59-62.

Rajan, S.A. and D. Radhakrishna (2013). Effect of entophytic bacteria on the rooting and establishment of cuttings of Hibiscus rosa sinensis. Journal of Agriculture and Veterinary Science, 3(2): 17-21.

Raviv, M. and O. Reuveni (1984). Endogenous content of a leaf substances associated with rooting ability of avocado cuttings. J. Amer. Sco. Hort. Sci., 109(3): 284287.

Ray, R.N.; A.K. Dwivedi; P.S. Rao and B.P. Jain (2001). Effect of indole butyric acid and coloured wrapping material on propagation of litchi cv. Purbi. Haryana Journal of Horticultural Sciences, 30(3/4): 170-172.

Reddy, P.P.N.; N.R. Ray; A.D. Patel and J.S. Patel (2014). Effect of rooting media and IBA (indole butyric acid) levels on rooting and survival of air layering in fig (Ficus carica L.) cv. POONA under middle Gujarat agro-climatic conditions. Theasian Journal of Horticulture, 9(1): 1-5.

Rinallo, C.; L. Mittempergher; G. Frugis and D. Marriott (1999). Clonal propagation in the genus Ulmus: Improvement of rooting ability by Agrobacterium rhizogenes T-DNA genes. Journal of Holt. Sci. and BioTech., 74(4): 500-506.

Rymbai, H. and G.S. Reddy (2010). Effect of IBA, time of layering and rooting media on air-layers and plantlets survival under different growing nursery condition in guava. Indian Journal of Horticulture, 67: 99-104.

Scagel, C.F. and R.G. Linderman. (1998). Influence of ectomycorrhizal fungi inoculation on growth and root IAA concentrations of transplanted conifers. Tree Physiol., 18: 739-747.

Scagel, F.C.; K. Reddy and J.M. Armstrong (2003). Mycorrhizal fungi in rooting substrate influences the quantity and quality of roots on stem cuttings of hik's yew. HortTech., 13: 62-66.

Singh, D.B. and R.K. Singh (1996). Effect of IBA on rooting of stem cutting and air layering of guava (Psidium guajava L.) cv. Allahabad surkha, Prog. Hort., 28(1-2): 51-53.

Singh, P.; J. Chandrakar; A.K. Singh; V. Jain and S. Agrawal (2007). Effect on rooting in guava cv. L-49 through PGR and organic media under Chhattisgarh condition. Acta Hort., (735): 197-200.

Steenhoudt, O. and J. Vanderleyden (2000). Azospirillum, a free-living nitrogen-fixing bacterium closely associated with grasses: genetic, biochemical and ecological aspect. FEMS Microbiology Reviews 24: 487-506.

Suresh, K.; D. Thippesha and M. Ganapathi (2016). Effect of growth regulators on rooting of air-layers of rose apple (Syzigium jambos L.). Res. Environ. Life Sci., 9(10): 1229-1231.

Vardar, Y. (1968). The Transport of Plant Hormones. North-Holland 
Pub. Comp., Amsterdam, Holland, pp. 407.

Wells, R. (1986). Air layering: An alternative method for the propagation of Mahonia aquifolia 'Compacta'. Comb. Proc. Intl. Plant Prop. Soc., 36: 97-99.

Yang, Y.; M. Tang; R. Sulpice; H. Chen; S. Tian and Y. Ban (2014). Arbuscular mycorrhizal fungi alter fractal dimension characteristics of Robinia pseudoacacia L. seedlings through regulating plant growth, leaf water status, photosynthesis, and nutrient concentration under drought stress. Journal of Plant Growth Regulation, 33: 612-625.

Yasser, A.S. (2015). Effect of growth regulators and bio-fertilizers on rooting and growth of pomegranate
(Punica granatum L.) stem cuttings. M.Sc. (Hort) Thesis, Univ. Hort. Sci., Bagalkot.

Yeboah, J.; B.K.B. Banful; P.Y. Boateng; F.M. Amoah; B.K. Maalekuu and S.T. Lowor (2014). Rooting response of air-layered shea (Vitellaria paradoxa) trees to media and hormonal application under two different climatic conditions. American Journal of Plant Sciences, 5: 1212-1219.

Zenginbal, H. and T. Demir (2018). Effects of some rhizobacteria and indole-3-butyic acid on rooting of black and white mulberry hardwood cuttings. The Journal of Animal and Plant Sciences, 28(5): 1426-1431. 


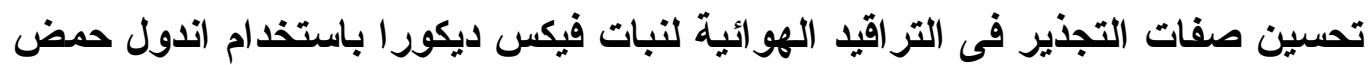

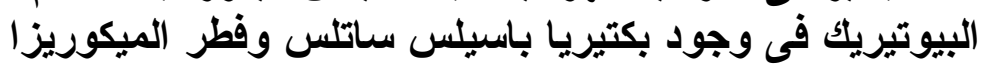

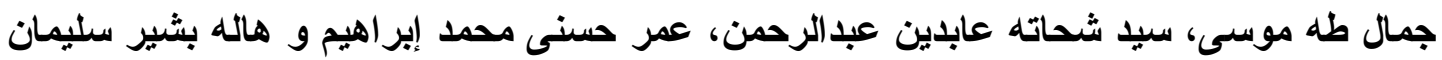
قسم الزينة وتنسيق الحدائق - كلية الزر اعة - جامعة أسيوط

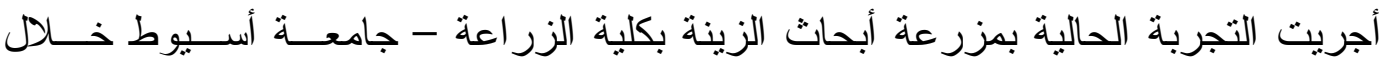

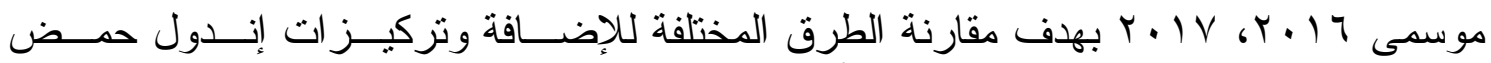

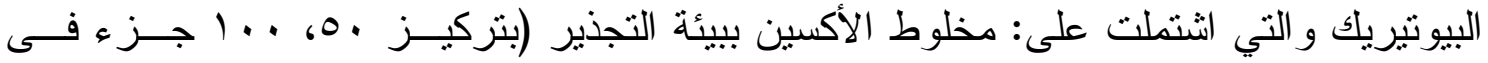

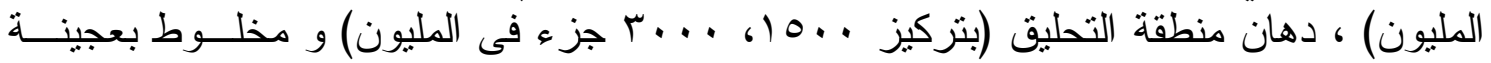

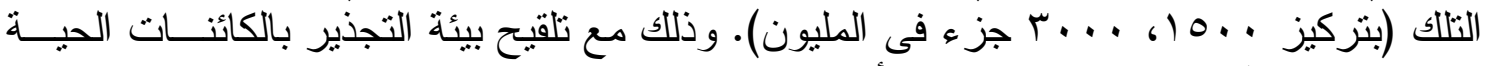

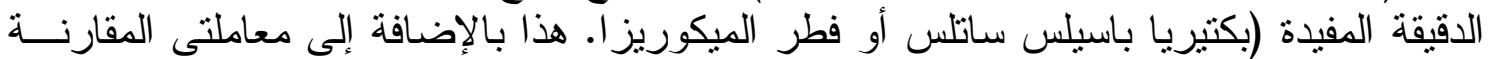

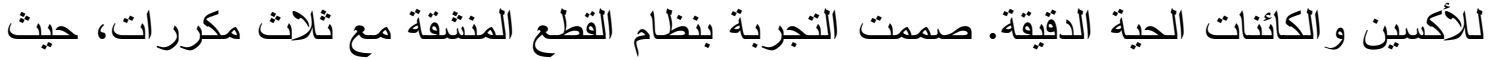

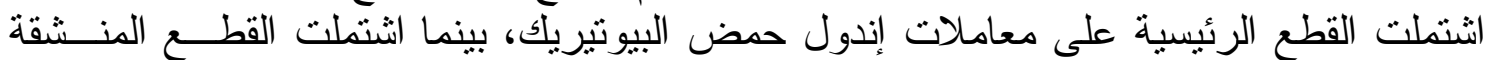

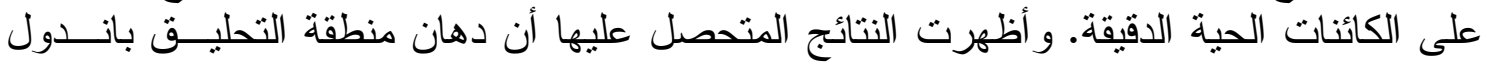

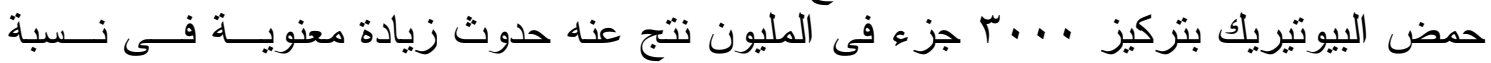

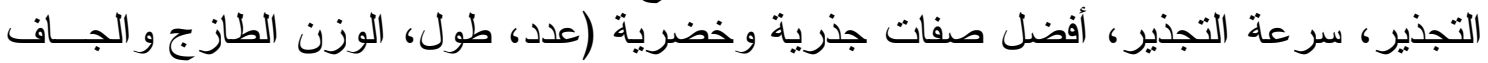

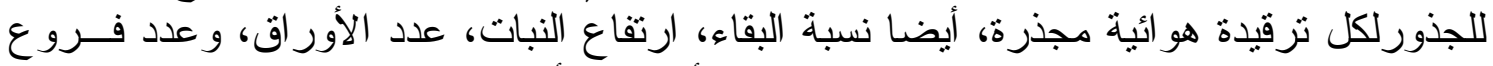

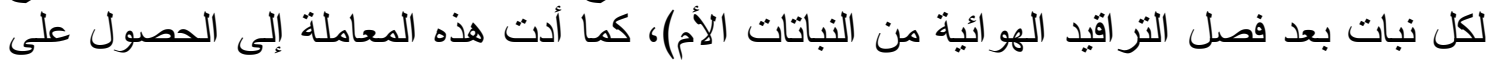

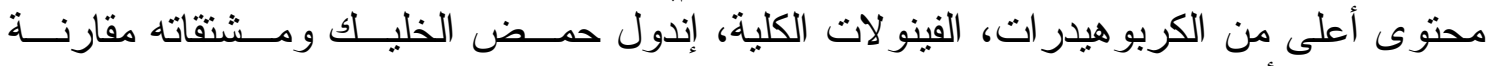

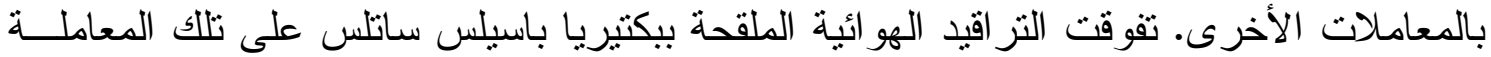

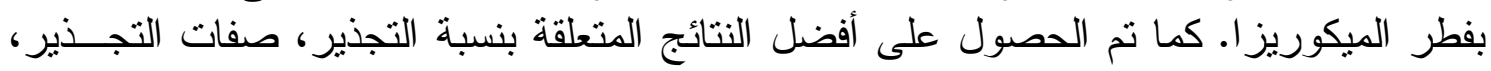

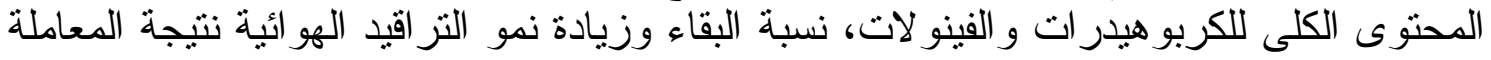

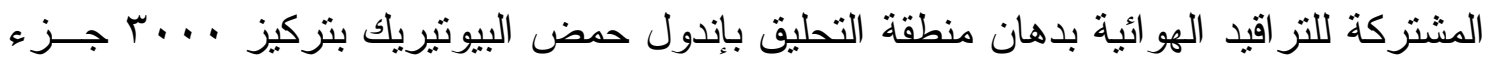

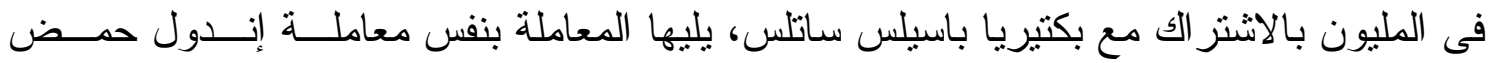

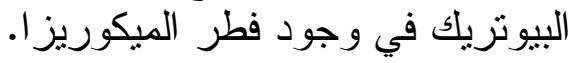

